\title{
Paradigma Pemberdayaan Ekonomi Rakyat: Keterpaduan Sektor Formal dan Informal
}

\author{
Edy Suandi Hamid
}

The people economy is often called the economic life of people, this terminology contains specific meaning. The economy of people describes the actor of economy, but the economic life of people explains the economical system. The Indonesian people economy play important role for Indonesian economy, and also it is motivated and supported by indonesia government. For that reason, the strict policy for economy is needed in order economy unit can develop in particular to increase Indonesian national output. Finally, the Indonesian economy building towards to a just, prosperous, welfare, and independent society.

Kata kunci: paradigma, ekonomi kerakyatan dan kebijakan.

\section{$D$} aradigma (paradigm) merupakan suatu konsep dasar yang dianut oleh suatu masyarakat tertentu, termasuk masyarakat ilmuwan (Suriasumantri, 1996). Paradigma juga diartikan sebagai suatu pola pandang (pattern of the declension) terhadap sesuatu. Dalam pengertian yang lebih umum, paradigma tersebut dianggap sebagai suatu yang secara umum diterima sebagai kebenaran atau yang perlu dilakukan. Sedangkan, pemberdayaan mengandung makna untuk membuat sesuatu lebih baik, lebih berdaya guna, atau bisa juga memperkuat atau memperkokoh.

Bagaimana dengan ekonomi rakyat sendiri? Ekonomi rakyat sering disebut dengan berbagai istilah lain yang terkait, yaitu perekonomian rakyat ataupun ekonomi kerakyatan. Ini mengandung makna yang spesifik. Jika ekonomi rakyat menggambarkan tentang pelaku ekonominya, maka perekonomian rakyat lebih menunjuk pada obyek atau situasinya. Makna yang lebih luas ada dalam ekonomi kerakyatan yang mencerminkan suatu sistem perekonomian.

Jika melihat secara harfiah, kata rakyat merujuk pada semua orang dalam suatu wilayah atau negara. Dengan demikian, jika dilihat dari terminologi ini, maka yang dimaksud dengan ekonomi rakyat adalah ekonomi seluruh rakyat Indonesia. Namun demikian dalam konteks riil yang berkembang, istilah ekonomi rakyat muncul sebagai akibat ketidakpuasan terhadap perekonomian nasional yang bias kepada unit-unit usaha besar. Oleh karena itu, makna ekonomi rakyat leih merujuk pada ekonomi sebagian besar rakyat Indonesia, yang umumnya masih tergolong ekonomi lemah, bercirikan subsisten (tradisional), dengan modal dan tenaga kerja keluarga, serta teknologi sederhana. Dengan demikian, kálau kita melihat realitas 
ekonomi Indonesia, sebagian ekonomi rakyat ini masuk kategori sektor informal, yang menyebar di pedesaan dan perkotaan. Dalam terminologi ekonomi yang ada dalam buku teks ekonomi, sebagian sektor ini sering dikategorikan juga sebagai underground economy, suatu kegiatan yang secara faktual terjadi namun aktivitasnya tidak selalu tercatat kontribusinya dalam perhitungan pendapatan nasional.

Ekonomi rakyat dibedakan dari ekonomi konglomerat dalam sifatnya yang tidak kapitalistik. Ekonomi konglomerat yang kapitalistik menomorsatukan pengejaran keuntungan tanpa batas dengan cara bersaing, kalau pertu saling mematikan (free fight competition). Sebaliknya, dalam perekonomian rakyat semangat yang lebih menonjol adalah bekerja sama, karena hanya melalui kerja sama berdasar asas kekeluargaan tujuan usaha dapat dicapai (Mubyarto, 1998: 40-46).

Bagaimana dengan pengertian ekonomikerakyatan yang banyak menjadi wacana dalam pembangunan ekonomi indonesia satu dasawarsa terakhir ini? Adalah tidak mudah membuat suatu batasan tentang ekonomi kerakyatan dengan hanya melihat dari sisi harafiah atau terminologi bahasanya saja. Karena kalau dilihat dari pelaku-pelaku ekonomi yang ada, baik itu unit usaha kecil, menengah, besar ataupun konglomerat, semuanya adalah "rakyat Indonesia". Artinya aktivitas produksi, konsumsi dan distribusi itu juga dilakukan oleh rakyat. Namun nafas dari ekonomi kerakyatan belakangan ini tidaklah demikian. Kesan yang kuat adalah adanya keinginan agar dalam pembangunan ekonomi ini keterlibatan rakyat banyak adalah perlu diperbesar atau ditingkatkan. Aktivitas-aktivitas ekonomi yang dilakukan melibatkan sebagian besar rakyat. Dengan dasar itu, maka dapat dikatakan, bahwa makna "ekonomi kerakyatan" tersebut adalah suatu perekonomian yang orientasinya pada keterlibatan orang banyak dalam aktivitas ekonomi, yakni aktivitas produksi, aktivitas konsumsi dan aktivitas distribusi (Hamid dan Hendrianto, 2000).

\section{Kontribusi Ekonomi Rakyat}

Dengan bersandar pada'pengertian tersebut, maka kita dapat melihat fakta bahwa ekonomi rakyat ini terus berkembang dari waktu ke waku. Namun demikian, perkembangannya tidak sejalan dengan perkembangan perekonomian secara keseluruhan. Ekonomi rakyat berkembang, dilihat dari sisi outputnya, lebih lamban dari perekonomian modem dan skala besar, yang pelaku dan kepemilikannya terbatas. Sebagai gambaran, misalnya, dapat dilihat dari struktur ekonomi rakyat yang terbesar, yakni sektor pertanian. Kontribusi sektor ini terhadap PDB semakin mengecil, dan ini memang sesuai dengan strategi pembangunan yang diarahkan untuk mengurangi corak agraris dalam strukturproduksi nasional. Namun demikian, transformasi struktural dalam PDB ini tidak diikuti dengan transformasi dalam distribusi penyerapan tenaga kerjanya. Menurunnya output (PDB) sektor pertanian, tidak diikuti dengan penurunan pekerja dalam sektor tersebut. Ini menggambarkan bahwa secara proporsional pendapatan ekonomi rakyatyang paling dominan ini secara relatif semakin miskin dibandingkan dengan sektor-sektor lainnya, terutama sektor industri.

Ekonomi (sebagian besar) rakyat Indonesia sejauh ini masih memberikan kontribusi relatif kecil dalam output nasional, demikian pula pangsa pasar yang dikuasainya. Namun demikian dari sisi jumlah pelakunya atau unit usaha serta 
penyeràpan tenaga kerjanya ternyata sangat dominan dibanding ekonomi usaha besar dan konglomerat (UBK) (Tabel 1)

Peran penting lain dari ekonomi rakyat adalah dalam penyerapan tenaga kerja. kecil, yang merupakan usaha sebagian besar rakyat Indonesia, bisa membantu memecahkan masalah pengangguran: Sebagaimana ditunjukkan tabel di atas, unit usaha kecil rata-rata hanya membutuhkan

Tabel 1: Struktur Ekonomi Indonesia (dailam persen)

\begin{tabular}{|c|c|c|}
\hline 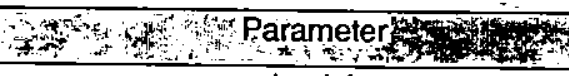 & 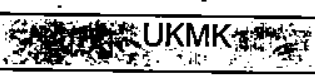 & EOBK \\
\hline Jumlah & $99,8(99,9)$ & $0,2(0,1)$ \\
\hline Kontribusi terhadap PDB & $39,8(59,36)$ & $60,2(40,6)$ \\
\hline Pangsa pasar & 20 & 80 \\
\hline Pertumbuhan ekonomi & $1 \overline{16,4}$ & $\overline{83,6}$ \\
\hline
\end{tabular}

Sumber : BPS yang diolah Bambang Ismawan (2004)

Keterangan:

UKMK : Úsaha Kecil, Menengah dan Koperasi

UBK : Usaha Besar dan Konglomerasi

Tanda kurung menunjukkan situasi setelah krisis

Masalah kekurangan kapital (investasi) yang dihadapi indonesia dipecahkan dengan pola investasi yang padat tenaga kerja. Data empirik menunjukkan, dengan investasi terbatas unit usaha ekonomi rakyat bisa menciptakan lebih banyak unit usaha dan juga kesempatan kerja (Tabel 2).

Tabel di atas menyiratkan bahwa dengan investasi relatif sedikit usaha-usaha
Rp̀ 1,5 juta per unit usaha per tahun, dan untuk usaha menengah adalah $R p$ 1,3 miliar per usaha per tahun. Jadi, jika unit usaha besar dengan investasi Rp 91,4 miliar hanya bisa menciptakan satu unit usaha, maka dengan investasi yang sama bisa diciptakan 61 ribu unit usaha baru pada di usaha kecil. Oleh karena itu, tidak mengherankan jika dari sisi pelakunya sebagian besar pelaku

Tabel 2: Rata-rata Investasi Kegiatan Ekonomi Lokal (2000-2003)

\begin{tabular}{|c|c|c|c|}
\hline 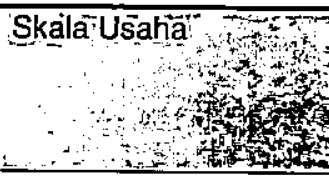 & 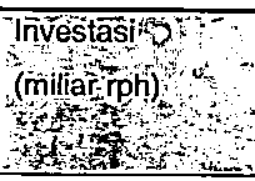 & 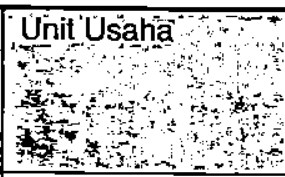 & 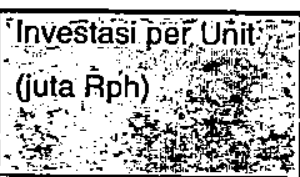 \\
\hline Kecil - & 58.884 & 40.138 .823 & $-1,5$ \\
\hline Menengah & 73.191 & 56.709 & $1.290,6$ \\
\hline Besar & 185.043 & 2.024 & $91.424,2$ \\
\hline Totally & $3177^{4} 18$ & 409197556 & 79 \\
\hline
\end{tabular}

Sumber: Berita Statistik No. 21/NI/24 Maret 2004 yg dikutip oleh Bappenas 2004. 
ekonomi Indonesia tergolong usaha menengah dan kecil, temasuk usaha mikro.

Banyaknya unit usaha yang bisa diciptakan dengan investasi terbatas di usaha kecil, mencerminkan juga banyaknya kesempatan kerja baru yang dapat diciptakannya jika unit usaha tersebüt didorong untuk tumbuh dan berkembang. Dengan data di atas dapat-dikemukakan bahwa unit usaha kecil dan menengah bisa lebih diharapkan untuk mengatasi salah satu masalah utama di negara kita, yakni masalah kemiskinan dan pengangguran. Oleh karena itu pengangguran membutuhkan perubahan paradigma pembangunan yang tidak bias pada skala usaha besar (padat modal), melainkan sebaliknya untuk lebih memberi kesempatan lebih banyak pada unit usaha ekonomi rakyat, yakni unit usaha kecil, termasuk usaha mikro, dan menengah. Namun demikian ini tidak berart bahwa skala besar dihambat pertumbuhannya. Unit usaha besar tetap penting untuk menopang pertumbuhan ekonomi. Namun usaha kecil perlu lebih diperhatikan dibandingkan yang sudah-sudah. Dorongan ini antara lain dalam bentuk memberi peluang usaha lebih besar, bantuan permodalan, pemasaran, pembinaan, dan sebagainya.

\section{Perlu Dukungan Kebijakan Publik}

Dari Tabel 1 di atas terlihat, unit usaha besar yang jumlahnya hanya $0,2 \%$ menguasai lebih dari $60 \%$ PDB. Pangsa pasarnya lebih besar lagi, yakni mencapai $80 \%$, yang berarti hanya menyisakan $20 \%$ untuk $99,8 \%$ pelaku ekonomi di tanah air. Ketimpangan lain ditunjukkan dalam kontribusinya untuk mendukung pertumbuhan ekonomi. Segelintir unit usaha besar tersebut merupakan "mesin" pertumbuhan yang memberi andil $83,6 \%$ atas laju perekonomian Indonesia.
Ketimpangan yang demikian tinggi berpotensi untuk munculnya kecemburuan sosial, yang bukan saja mengancam semua pelaku ekonomi tersebüt, melainkan juga stabilitas dalam masyarakat. Unit usaha besar juga tidak bisa bertahán lama apabila potensi pasarnya dari UKMK tidak berkembang. Apalagi jika dilihat karakteristik UBK di tanah airyang sangat tinggi konsentrasinya, namun orientasi ekspornya sangat rendah, atau dikenal dengan istilah "jago kandang".

Dapat dikatakan bahwa fondasi ekonomi Indonesia sejak lama sebenarnya adalah berbasiskan perekonomian rakyat. Dilihat secara absolut, dari 39,72 juta unit usaha (1972), sebanyak 39,71 juta merupakan sektor ekonomi rakyat. Ekonomi rakyat ini juga yang mampu bertahan pada saat krisis ekonomi terjadi. Angka yang ada menunjukkan pada saat krisis jumlah UKMK ini justru bertambah dari $99,8 \%$ menjadi $99,9 \%$, dan kontribusinya terhadap PBD juga naik dari $39,8 \%$ menjadi $59,36 \%$ (Tabel 1). Oleh karena itu, tidak mengherankan kalau ekonomi rakyat sering diberi predikat sebagai "katup pengaman perkonomian nasional". Namun demikian dalam realitas kebijakan publik, ekonomi rakyat ini pula yang seolah selalu tersia-sia, kurang mendapat perhatian/perlindungan, dan juga tidak dipercaya. Fasiltas yang diberikan pada usaha kecil sangat terbatas. Salah satu masalah yang banyak dihadapi oleh usaha kecil menengah adalah berkaitan dengan permodalan. Sumber dana yang digunakan umumnya adalah dari modal sendiri, atau modal keluarga. Sumber dana dari pihak luar umumnya berasal dari lembaga keuangan informal, yang biasanya mengenakan bunga yang tinggi. Hal ini dilakukan karena para pelaku UKM sulit memenuhi persyaratan yang diminta oleh lembaga keuangan formal. Di samping persyaratan dan prosedur yang dipandang sukar, usaha ekonomi 
rakyat ini mayoritas dianggap tidak bankable, walaupun dilihat dari kelaikan usaha unit usaha tersebut banyak yang feasible.

Oleh karena itu, dalam konteks dukungan pada ekonomi rakyat ini perlu kebijakan yang tegas untuk membuka akses seluas-luasnya pada unit-unit usaha ekonomi rakyat yang kecil dan mikro. Sebagaimana dikemukakan di atas, hambatan utama bagi unit usaha ini adalah ketiadaan jaminan (collatera). Di sisi lain, perbankan secara ketat menerapkan prinsip prudential banking yang mengharuskan adanya jaminan tersebut. Akibatnya usaha kecil hanya mengandalkan modal sendiri atau dengan meminjam dari pelepas uang dengan tingkat bunga yang sangat tinggi sehingga menyulitkan perkembangan usaha lebih lanjut. Kebijakan yang membuka akses pada lembaga keuangan formal tersebut seharusnya dilakukan secara menyeluruh di tanah air dengan cara (a) menyediakan lembaga keuangan nonbank yang memberi peluang usaha ekonomi rakyat untuk meminjam tanpa jaminan; (b) pemerintah (Pusat/Daerah) membeli premi risiko lembaga keuangan bank; dan dalam jangka panjang kemungkinan mengkaji untuk mengamandemen UU Perbankan yang membuka peluang memberikan pinjaman tanpa jaminan.

Penyediaan-kredit tanpa agunan dengan premi risiko yang ditanggung Pemerintah, atau (Pusat ataupun Daerah). Penyediaan dana kredit untuk UKM tanpa agunan sudah mulai disadari dan dilakukan oleh beberapa peimerintahan di daerah. Sejak tahun 2004, misalnya, Pemerintahan di Kabupaten Kutai Barat yang hampir separo penduduknya (2002) miskin, telah mengalokasikan dana kredit tanpa agunan sebanyak Rp 5 miliar untuk UKM (Usaha Kecil dan Menengah). Ini dapat dikatakan sebagai suatu perubahan paradigma dalam perkreditan UKM di Kutai Barat. Pemerintah Kabupaten Kutai Barat menyadari bahwa sebagian unit usaha kecil-menengah ini memiliki keterbatasan modal, tidak mempunyai harta-benda untuk jaminan, atau karena ketiadaan surat-surat formal yang berkaitan dengan kepemilikan harta atau izin usahanya. Pinjaman tertinggi yang diberikan untuk UKM tersebut mencapai Rp 50 juta. Pola pembayaran pinjaman ini juga disesuaikan dengan pola pendapatan/ penerimaan masyarakatnya. (Hamid, 2004). Kebijakan yang dilakukan Pemkab Kutai Barat ini merupakan contoh riil perubahan paradigma dalam pemberdayaan ekonomi rakyat.

Contoh lain kebijakan publik .yang berupaya merubah paradigma dengan memberdayakan ekonomi rakyat adalah Program Inpres Desa Tertinggal (1984-1999). Dikatakan merubah paradigma karena (1) program IDT secara berpihak pada orang miskin dengan memberikan kepercayaan pada mereka, dan pemerintah hanya sebagai pendorong; (2) program IDT bukan merupakan suatu "proyek", sehingga tidak ada management fee, dan biaya-biaya pengelolaan proyek lain, dan (3) program IDT adalah program pemberdayaan menuju keswadayaan dan kemadirian ekonomi rakyat. Dana IDT tersebut dikelola sendiri oleh kelompok masyarakat miskin (Mubyarto, 1998). Walaupun tidak semuanya sukses, beberapa program IDT menunjukkan hasil signifikan, seperti dilaporkan BPS (1997), sebanyak 19 provinsi dampak ekonomi program IDT sudah menentuh $50 \%$ penduduk miskin. Bahkan di:DIY mencapai $90 \%$.

\section{Pemberdayaan dan Keterkaitan}

Dalam rangka pemberdayaan ekonomi rakyat, idealnya, antara UKMK dan UBK 
daiam seluruh aktivitas usahanya ada ada saling keterkaitan (backward maupun forward linkages) dan bekerja atas dasar kemitraan (partnership). Pola keterakitan dan kemitraan diharapkan bisa mengangkat skala usaha yang rendah menjadi lebih besar. Hal ini bukan saja akan memperkuat struktur dan daya tahan ekonomi nasional, melainkan juga dalam jangka panjang akan dapat menguntungkan unit-unit usaha tersebut, baik skala kecil maupun besar. Secara normatif, konsep kemitraan merupakan pelaksanaan dari prinsip tolongmenolong, dan mengurangi konsentrasi
UKMK dan UBK di tanah air.

Pengalaman empirik menunjukkan unitunit usaha besar yang berjalan sendirian dalam mendorong pertumbühan ekonomi nasional ternyata sangat rentan. Hal ini sangat berbeda dengan di Jepang yang keterkaitan dan kemitraannya sangat tinggi. Contoh "klasik" yang sering ditunjukkan adalah pada industri mobil, yang melibatkan ribuan ribuan subkontraktor sekunder dan puluhan ribu subkontraktor tersier dari unit usaha kecil dan menengah.

Gambar piramida di atas menunjukkan

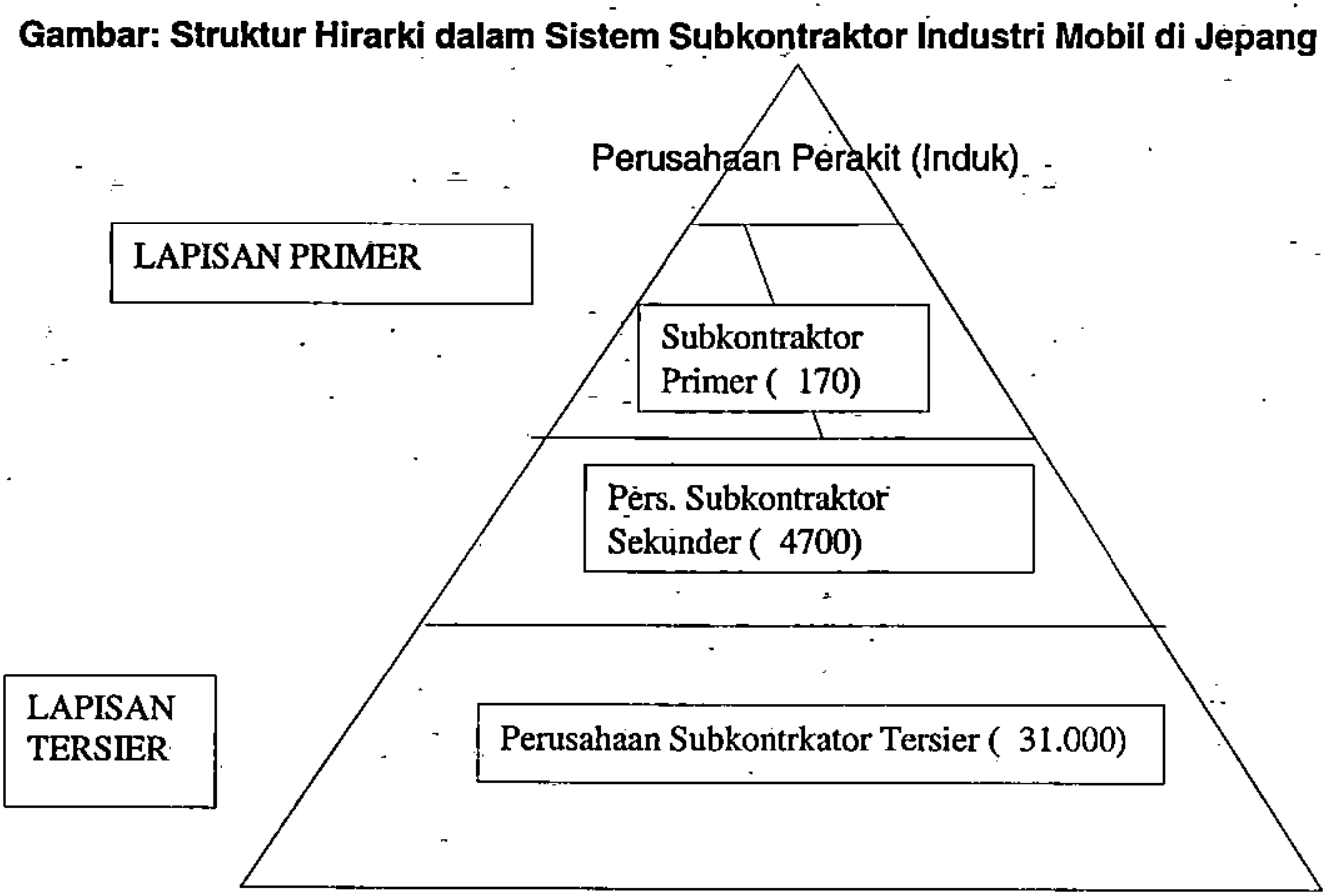

Sumber: Konno dan Takasu sebagaimana dikutip Thee Kian Wie (1992) .

kepemilikan yang memunculkan ketidakadilan. Namun kenyataannya hal yang demikianmasih jauh dari mewujud. Unit-unit usaha yang ada lebih banyak berjalan sendiri-sendiri. Akibatnya, ketimpangan yang besar terjadi antara betapa tingginya ketergantungan suatu industri mobil di Jepang pada unti-unit yang ada di bawahnya. Hal demikian terjadi karena mereka secara ketat menerapkan prinsip spesialisasi, yang dituntut dalam rangka menghasilkan kualitas output yang 
baik dengan biaya yang efisien. Perusahaan mobil yang bersaing ketat di pasar tidak bisa menghasilkan semua komponennya, karena akan berakibat pada mahal biaya produksi. Dengan demikian, tuntutan pasar yang menyebabkan terjadinya keterkaitan dan kemitraan tersebut. Antartingkatan perusahaan tersebut Ada tuntutan saling membutuhkan antar tingkatan perusahaan.

Pola keterkaitan seperti yang terjadi di Jepang tersebut bisa saja secara meluas dilakukan di Indonesia antara unit-unit usaha industri di sektor formal dengan unit-unit usaha menengah maupun kecil, yang umumnya masuk kategori sektor informal. Bahkan dengan pola keterkaitan ini. diharapkan bisa mengangkat sektor-sektor informal tersebut masuk dalam sektor formal sehingga memudahkannya untuk berkembang leih lanjut. Jika dilihat pelaksanaan kemitraan di tanah air, keterkaitan-dan kemitraan yang terjadi selama ini lebih karena dorongan keterpaksaan, bukan sesuatu yang saling membutuhkan. Hal ini terjadi karena berbagai kebijakan pemerintah yang ada memang kurang mendukung iklim kemitraan tersebut. Unit-unit skala besar merasa lebih memperoleh keuntungan apabila semuanya dilakukan secara mandiri. Misalnya saja, ada unit usaha yang melakukan integrasi dari-hulu sampai hilir, atau melakukan integrasi vertikal dan horisontal. Dengan pola seperti ini, peluang untuk kemitraan dan keterkaitan menjadi tertutup. Padahal pola ini mengandung banyak manfaat, antara lain (1) ekspansi bisnis yang dilakukan usaha besar, akan diikuti pula oleh ekspnasi bisnis skala menengah dan kecil sehingga kenaikan pendapatan terjadi di semua tingkatan usaha; (2) mengurangi kesenjangan ekonomi antar unit usaha yang ada; dan (3) mendorong peningkatan produktivitas dari setiap unit ekonomi yang ada; dan (4) pemerataan partsipasi semua pelaku bisnis dalam kegiatan ekonomi.

Dengan kondisi yang ada saat ini, maka perlu agenda yang jelas untuk membangun -kemitraan tersebut. Yakni suatu kemitraankemitraan yang didasarkan pada kondisi saling membutuhkan, saling menguatkan, dan saling menguntungkan. Dengan kondisi yang demikianlah kemitraan bisa terbentuk secara efisien dan adil.

Dalam konteks Indonesia, upaya mewujudkan kemitraan antarskala usaha ini merupakan bagian dari reformasi atau restrukturisasi ekonomi yang sedang berjalan. Sebagaimana dikemukakan Umer Chapra (2000:83) restrukturisasi ekonomi ini dapat dilakukan dengan memperkuat nilajnilai moral yang memungkinkan individu memenuhi kepentingannya-dalam batasbatas kesejahteraan sosial dan stabilitas ekonomi. Unsur moral inilah yang menjadi salah satu tekanan dalam Sistem Ekonomi Pancasila yang dikembangkan PUSTEP UGM, yang tidak memandang manusia semata-mata sebagai homo economicus, melainkan juga sebagai homo-ethicus dan homo-socius. Tujuan dari restrukturisasi tersebut antara lain adalah mereduksi konsentrasi kepemilikan sarana-sarana produksi yang kini sedang berjalan sebanyak mungkin untuk melengkapi transformasi moral dalam mminimalkan pengaruh kekuasaan dan kekayaan dalam alokasi dan distribusi sumber-sumber daya (loc.cit)

Proses seperti itu dapat terjadi jika pemerintah memberikan iklim yang mendukung terjadinya keterkaitan dan kemitraan tersebut. Di samping itu, pada tahap awal untuk mengembangkan kemitraan tersebut pemerintah perlu memberikan insentif kepada pihak-pihak yang terkait tersebut, misalnya saja berupa insentif fiskal (pajak/subsidi) maupun 
insentif moneter (permodalan/dana murah). Di samping itu, Badan-badan Usaha Milik Negara (BUMN), yang secara tegas juga memiliki fungsi sosial, juga perlu memeloporì program kemitraan ini dalam melaksanakan aktivitas bisnisnya.

\section{Penutup}

Dengan uraian dan data di atas, kiranya cukup memberikan gambaran bahwa ekonomi rakyat di Indonesia bukan saja. telah memberikan peran yang besar bagi ekonomi nasional, namun juga perlu untuk terus mendapat dorongan dari pemerintah pusat maupun daerah. Ini dimaksudkan agar ekonomi rakyat ini juga bisa memiliki. produktivitas yang setara dengan produksi usaha besar. Oleh karena itu, kebijakan yang secara tegas berpihak kepada ekonomi diperlukan agar unit ekonomi ini bisa terus berkembang, baik dalam menyerap tenagakerja, meningkatkan output nasional, sehingga bisa membawa ekonomi Indonesia ke arah pewujudan masyarakat yang adil, makmur; sejahtera, dan mandiri.

\section{Daftar Pustaka}

Badan Pusat Statistik, BAPPENAS, dan UNDP, 2004, The Economics of Democ: racy-Financing Human Development in Indonesia, BPS, BAPPENAS, dan UNDP

Bappenas, 2004, Prespektif Teoritis Konsep Dasar Pengembangan Ekonomi Lokal(Draft-belum dipublikasikan), 2004, Jakarta: Bappenas,

Chapra, Umer, 2000, Islam dan Pembangunan Ekonomi, Jakarta: Gema Insani, .
Hamid, Edy Suandi, 2003, "Penanggulangan Kemiskinan dan Ekonomi Rakyat", Makalah dalam Form Kajian tentang Penanggulangan Kemiskinan dan Ekonomi Rakyat yang diadfakan Badan Informasi Daerah Yogyarakta tangal 25 Oktober 2003, Yogyakarta

Hamid, Edy Suandi, 2004, "Perubahan . Paradigma Kredit UKM Kutai Barat" Draft Laporan Penelitian, Pemkab Kutai Barat dan Pusat Studi Ekonomi Pancasila (PUSTEP) UGM, Yogyakarta -

Ismawan, Bambang, 2004, "Sektor Ekonomi Rakyat dan Peran Keuangan Mikro" Makalah pada Forum Dialog Kebangsaan Program AksiMeluruskan Reformasiyang diadakan Universitas Gadja Mada 11-14 Maret 2004, Yogyakarta

Mubyarto, 1998, Reformasi Sistem Ekonomi, Yogyakarta: Aditya Media.

Mubyarto, .2003, Ekonomi Pancasila: Renungan Satu Tahun Pustep UGM, Indonesia, Yogyakarta: PUSTEP UGM,

Mubyarto, 2004, Teknokrat dan Ekonomi Pancasila, Yogyakarta: PUSTEP UGM:

Thee Kian Wie (ed, 1992), Dialog Kemitraan dan Keterkaitan Usaha Besar dan Kecil dalam Sektor Industri Péngolahan, Jakarta: Gramedia.

UNDP, 2003, Human Development Report, 2003, New York: Oxford University Press. 
Pardigma Pemberdayaan Ekonomi Rakyat; Edy Suandi Hamid

Suriasumantri, Jujun S, 1996, Filsafat IImu

Sebuah Pengetahuan Populer,

Jakarta : Sinar Harapan, 